\title{
Law in the institutional system of modern societies: the value aspect
}

\author{
Valery Glazyrin* \\ Department of Philosophy and Sociology, Ural State Law University, Ekaterinburg, Russia
}

\begin{abstract}
People as intelligent and socio-cultural beings give their being a value dimension, which allows them to develop an idea of "who we are" and strive for the organization of public life for the benefit of citizens. In modern societies, constitutional democracies, the values of the rule of law, inviolability of human dignity, legal freedom and human rights constitute the semantic basis for these societies. Outside of these values and legal institutions, modern constitutional and legal societies cannot exist. Social reality can be much "worse" than the legal values proclaimed and enshrined in constitutional acts. Modern societies are complex social systems. Their institutional structure is not limited to legal regulations, and the spectrum of public values is not limited to the area of legal values. The article emphasizes that moral maxims and other value formations cannot replace legal values. The purpose of this work is to study the role of value phenomena in maintaining the legal foundations of modern societies, to show the importance of legal values in comparison with other social values in ensuring the rule of law in modernist democratic societies.
\end{abstract}

\section{Introduction}

Values are of fundamental importance for people as social beings; they form the world of meanings, influence the f guidelines and goals for social actors, act as the primary basis for structuring societies, social regulation and rule-making.

In any society, there is a social order. In archaic societies, there are no legal institutions for reproducing the social order. In the long social evolution, societies whose institutional framework is legal regulations develop. The effectiveness of legal prescriptions in maintaining social order, understanding their possible imperfections is ensured by their official status and general obligation, the certainty of legislative acts, precedents, the judicial system, and the imperious state enforcement of laws. However, not all legal orders are legal. The legal order is based on legal statutes established by government authorities. In the extreme, the legal social order could be called the "dictatorship of law."

From the standpoint of legalism, any legalized social order can be considered legal. But dictatorial regimes cannot be considered legal. The legal order is "built" on laws. The legal institutional framework of the legal order is legal laws. The difference between legality and law and order is due to the fact that lex ("rule of government") does not coincide with jus ("rule of law"). The dissimilarity of social orders and the "dictatorship of law" should not be limited to the academic discussion of the concepts of "law". If they are identical, human rights and freedoms become an area of discretion of the rulers; and legal possibilities of citizens in asserting their rights can be restricted. To overcome the "dictatorship of law", it is necessary to use the value principles of law, bearing in mind that legal laws must comply with the nature and requirements of law, otherwise they can be used for nonlegal purposes [1, p. 37].

In philosophy, jurisprudence, history and other sciences, the knowledge of law as a value has a significant legacy, supplemented by the Constitutions of many countries, international and national political and legal acts, some of which are epoch-making intellectual breakthroughs in social and legal thought, legislative documents that have had a powerful impact on the development of human civilization (e.g., "Magna Carta" (1215), "Declaration of Independence of the United States" (1776), "Declaration of Human and Civil Rights" (1789), "Universal Declaration of Human Rights" (1948), "Convention on the Protection of person and fundamental freedoms "(1950).

The definition of law as a value has many facets. Since the issue of law as a value is extensive, many of its aspects will not be analyzed in this article. In a generalized form, the value of law is representation and awareness of the importance of Legal Freedom or, in other words, the Constitution of Freedom in the life of modern people, societies, and governments. The Constitution of Freedom presupposes the recognition of the value of the rule of law, which suggests that the value of law belongs to the highest social values.

Legal values enshrined in legal acts acquire an official legal status, become value-institutional units in the public relations. Thus, the Universal Declaration of Human Rights (Articles 1, 3, 4, 5, 6, 7, 9) declares the

Corresponding author: glazyrin_59@mail.ru 
following values: all people are born free and equal in their dignity and rights; everyone has the right to life, liberty and security of person; no one should be held in slavery or servitude, slavery and the slave trade are prohibited in all forms; no one should be subjected to torture or cruel, inhuman or degrading treatment or punishment; every person, wherever he is, has the right to recognition of his legal personality; all people are equal before the law and have the right to equal protection; no one can be arbitrarily arrested, detained or exiled.

The Constitution of Freedom cannot be complete without fixing the value of freedom and the principle of its implementation. Paragraph 1 of Article 4 of the Declaration of the rights and freedoms of man and citizen (Adopted by the Supreme Soviet of the RSFSR on November 22, 1991) declares that "the exercise of rights and freedoms should not violate the rights and freedoms of other people." Legal values and legal order has been changing the scope of public relations. In the legal space, the state becomes legal.

An example is Article 1 of the Constitution of the Federal Republic of Germany which says that 1) human dignity is inviolable. Respecting and protecting it is the duty of all government authorities. 2) On this basis, the German people recognize the inviolable and inalienable human rights as the basis of every community, peace and justice. 3)... fundamental rights are binding on legislators, administrative and judicial authorities as directly applicable rules. In this selective review of law as a value, it is necessary to emphasize the public purpose of an independent court, judicial protection of rights and freedoms. Thus, in modern societies, the values of law are origins of the legal social order, its foundation is the unconditional recognition of human dignity, human and civil rights and freedoms enshrined in the Constitutions.

There is a "gap" between the law as a value and legal reality (law de facto). Nevertheless, under no circumstances can such and other "failures of law" diminish the importance of legal values and legal order. It is obvious that social reality can be "worse" than the legal values publicly proclaimed and prescribed in constitutional acts, but it can hardly be "better". The triumph of law does not arise ex nihilo and cannot be bestowed by anyone. Therefore, the desire to establish law and legal values should be an immutable rule for citizens.

Societies are complex and dynamically changing social systems. The legal order is extremely important, but the range of values is not limited to legal values, it is much more extensive.

The value of law can be studied from different perspectives. One of the research approaches adopted in this article is to consider social value formations in their relation to the legal order. The purpose of the study is to consider the value of law in comparison with other social values

The study uses the sociological methodology "law and society" $[12,13]$. This methodology provides researchers with extensive and fruitful opportunities in the study of law, orientates them to a "volumetric" vision of the phenomenon of law, the problems of its social existence in societies, allows to consider law and its institutions as emerging, functioning and changing in societies, involves the study of direct and inverse relationships between society, as a complexly structured socio-cultural education and its legal system. Within the conceptual framework of this methodology, the study of law as a value is carried out on the basis of a theoretical premise about the complementarity of the value and legal structure of modern societies. This provision does not mean that the creation of Right Freedom societies is carried out according to the "templates" uniform for all states. Each country has its own historical trajectory of the formation and implementation of legal values and legal order. The work also uses the method of comparative analysis of various value complexes that exist in modern societies, the case-study method, induction and deduction.

The key publications used as the scientific basis for understanding the role of law in social systems and law as a value are philosophical and general theoretical works by V. Zhukov [2], V. Nersesyants [1], D. Lloyd [3] and R. Dworkin [4]. The ideas developed by D. North, J. Wallis, and B. Weingast [5] allow us to see the value aspect of law from the standpoint of institutionalism. Long-term studies of values by $\mathrm{R}$. Inglehart [6] and K. Welzel [7] demonstrate an understanding of values in the context of the cultural paradigm and show the value of law in the social dynamics of the "birth of freedom". The results of their surveys were presented in a visual form in the Inglehart - Welzel 'Cultural Map (8).

D. Acemoglu and J. Robinson [9], the authors of the concept of "narrow corridor" showed a diverse palette of their "failures" and "successes" in asserting the values of law.

\section{Results and Discussion}

Consider law as a value in its interaction with other social values.

Right as a value and Hobbesian Leviathan. It seems that any social order rests on a very fragile foundation, the life of people can be either "lonely, hopeless, poor, stupid and short" in a state of war of all against all, or be under the rule of the Leviathan state. The dilemma of possible social orders proposed by Hobbes would have been true if humanity had not been able to make the amazing social discovery of what law is. The valuebased and institutional response to the challenges of social chaos (everyone has the right to everything) and dictatorship (the social order of lack of freedom and lack of rights) is the legal order (the social order of legal freedom).

Where is the dividing line between the views of the author of the treatise on Leviathan and the understanding of the value of law, Legal Freedom? Comments, which consider the Hobbesian explanation of reasons for the emergence of a general war between people, argue that its "roots" are constrained by the egoistic nature of man 
and his passions, the understanding of its pivotal principle is overlooked.

Revealing the origin of the state of war of all against all, Hobbes developed the following sequence of reasoning. All people are born equal. Therefore, everyone has the right to everything which inevitably triggers a war between them. Under these circumstances, the question of their survival becomes important. The English philosopher believed that the solution to this existential problem was the Leviathan state, which would ensure safety of people in exchange for their rights. There is no need to explain whether people deprived of their rights can be considered free. The Hobbesian version of the social contract excludes law from the social relations. Hobbes failed to solve the riddle of law. But the main question is different. How to legally confront the dangers of war of all against all, establish a legal social order and ensure human rights?

The legal order has its features [10] and is prescribed in the Constitutions of democratic states. An example of a capacious and lapidary intellectual representation of law as a value is the description made by T. Jefferson, included in the US Declaration of Independence. This document says that the equality of people is a selfevident truth, they are endowed with the inalienable rights to life, freedom, happiness. To ensure their rights, citizens establish governments, whose legal powers are based on the consent of the governed. The people have the right to change, abolish, establish a new government, which will ensure safety and happiness of people.

Law as a value: "the right of force" and "the force of law". Law makes it possible to distinguish "the right of force" from the "force of law". It is difficult to imagine societies that will ever be able to exclude manifestations of "power" in social relations, for example, to get rid of crimes. But it is possible to carry out institutional transformations, ensure that "force" becomes an "element" of the legal order. This requires a legal monopoly on the use of force. The issue of legal institutionalization of violence is not simple; it has its own specifics in different countries and may be associated with the need to reform law enforcement bodies. An important feature of the legal institutionalization of violence in the United States is that the Second Amendment of the Bill of Rights (1791) establishes the right of people to keep and bear arms.

The world in the $21 \mathrm{st}$ century is undergoing significant changes. There are new dangers to human rights and freedoms and legal order. There are threats to citizens and societies from crime and terrorism. Security is needed to ensure the social legal order, but what is security without freedom? The value of security cannot exceed the value of law.

In explaining the relationship between freedom and security, at least two "mental traps" can be distinguished: it does not follow from the correct premise that "there is no freedom in the absence of security" that 1 . the more security, the more freedom, or that 2 - freedom and security have equal weight in modern societies. If we analyze them as the concepts "end" and "means", we will see that in constitutional orders security is a condition for freedom. Security is a means rather than an end, needed to ensure freedom. The main value of legal states is legal freedom.

Law as a value and morality. Law and morality are valuable and normative components of social order; they have areas of interaction. Moral values, ideas about good, evil and justice that have developed set a framework for social legal orders. There is no legal order without moral and ethical "pillars". The challenges associated with the development of genetic engineering presuppose answers to the most acute moral questions affecting the basic ideas about human existence.

The existence of links between law and morality does not mean that there are no differences between them. Realizing that morality and law evolve, morality cannot replace law. Therefore, the statement that law is a minimum of morality (V. Solovyov) does not describe the relationship between them; the idea that reduces law to external (imperious) regulators contradicts the position that rights and freedoms are given to people from birth. Both of these interpretations of law are examples of its depreciation.

A proper explanation of the role of law and morality in the legal order proceeds from the understanding that the legal order is constituted by a social contract (area of public relations) on rights. In the social contract, law has a priority over morality. Moral and ethical prescriptions become significant in public and private law when they become part of the social contract.

Law as a value and religion. The role of religion, canon law, is undoubted. There are countries where the legal order is determined by religion. These are clerical and theocratic states. Religious and clerical dogmas and values are the basis of the legal order. But in many countries, there are no religious foundations of law. In non-clerical states, law is not considered to be a project and an instrument for building the City of God on Earth. Legal values presuppose freedom of conscience; no religion can be compulsory; religious societies are separated from the government and equal before the law.

Law as a value and ideology. Are legal values and legal order determined by ideological doctrines? There should be an "ideological" perspective on the value of law and legal order, which implies the theoretical searches for the "idea of law", conceptual provisions on the rule of law, constitutional and legal research into the structure of states. Of course, law cannot be ideological; it is not a servant of "revolutionary expediency" and rulers' the legal standard does not allow the establishment of a mandatory ideology. The legal values are values of ideological diversity and multiparty systems.

Law as a value and legitimacy. Legitimacy is an important quality of law as a value. The legal order has a "dual" nature, it is legal and legitimate' it is clear that legality is a necessary, but not sufficient basis for recognizing the legal order as legal. The rule of law establishes (institutionalizes) the legal order. In turn, legitimacy is required to confirm that the existing legal order is based on the consent of citizens, constitutional and legal principles, a social contract on human rights and freedoms. The value of legitimacy in ensuring the political and legal stability cannot be neglected; even 
authoritarian (dictatorial) regimes resort to all kinds of political and technological simulacra to demonstrate their legitimacy.

Law as a value and traditional cultural values. Consideration of the value of law in the context of traditional cultural values is a difficult issue which requires an explanation of many aspects of social dialectics.

Societies have their own history and culture, influencing the people's identity. Legal societies are not created from scratch; new social orders are based on the social foundations. Movement into the future is associated with historical crossroads, windows of opportunities, responses of societies to internal and external challenges. It is true that the "new" social order outgrows the "old" one, which has become the order of the past. This position is also true for understanding the creation of legal societies. Legal values and institutions form a different social space than the one in traditional societies.

Legal order societies can include social and legal "components" of traditional relations, societies, in particular, business habits, customs and social habits. Nevertheless, the rule of law and the traditional order are different societies. The values of the first one are associated with the recognition of the equality of people, universal rules; in the second one, inequality in rights (for example, class, gender) is explicitly / implicitly cultivated.

Do the legal values and institutions in the West destroy cultures and identities of non-Western societies? It is impossible to deny difficulties and contradictions of the "inclusion" of modern legal standards and institutions into the structure of societies with different cultures, but historical realities, social changes do not fit into the mechanistic assumptions about the destruction of culture and identity of societies. Japan, Taiwan, Hong Kong, South Korea have mastered many Western legal values and institutions. At the same time, they have a unique, eastern (not western) culture; societies based on legal institutions are diverse cultural societies.

Law as a value and a Karamzin's incident. Karamzin said that Russia did not need a Constitution and new laws, but it needed 50 honest and sensible governors [11]. For the author of "History of the Russian State", institutions, including the legal ones, did not matter. State administration was reduced to manual control. This means that if there are no official and binding legal regulations, rules, officials and statesmen will be forced to implement managerial decisions and projects in a compulsory manner. In contrast to the views by Karamzin, the legal order is an institutional system of "impersonal" rules based on the recognition of the rule of law and legal laws.

\section{Conclusion}

Modern democratic societies are complex, changing social systems. Law as a value is a cornerstone of their value spheres. Right-wing values are enshrined in the
Constitutions and legislative acts, become guidelines for social actors, launch the process of development of societies of Legal Freedom (Constitutional Freedom). The goddess of history, Cleo, does not guarantee the triumph of Freedom of Law to any nation; however, she does not establish insurmountable obstacles. The choice should be made by people: right or lawlessness, freedom or lack of freedom, the rule of law or the rule of rulers. With all the diversity of values and institutions, there is no reasonable alternative to the legal order. Only under this social order, the equality of people, the inviolability of their human dignity, rights and freedoms are recognized.

\section{References}

1. V.S. Nersesyants, Philosophy of Law (Norm: INFRAM, Moscow, 2016)

2. V.N. Zhukov, Philosophy of Law (Moscow State University Publishing House, 2021)

3. D. Lloyd, The Idea of Law (Pelican Books, London, 1964)

4. R. Dworkin, Law's Empire (Harvard University Press, 1986)

5. D. North, J. Wallis, B. Weingast, Violence and Social Orders. A Conceptual Framework for Interpreting Recorded Human History (The Syndicate of the Press of the Cambridge University, 2009)

6. R. Inglehart, Cultural Evolution, People's Motivations are Changing, and Reshaping the World (Cambridge University Press, 2018)

7. C. Welzel, Freedom Rising. Human Empowerment and the Quest for Emancipation (Cambridge University Press, 2013)

8. Retrieved from: https://www.worldvaluessurvey. org/wVs.jsp

9. D. Acemoglu, J. Robinson, The Narrow Corridor: States, Societies, and the Fate of Liberty (Penguin Publishers, 2019)

10. Report on the rule of law. Approved by the Venice Commission at the 86th Plenary Session (Venice, 25-26 March 2011). Strasbourg, April 4, 2011. Retrieved https://www.venice.coe.int/webforms/ documents/default.aspx?pdffile $=\mathrm{CDL}$ $\mathrm{AD}$ (2011)003rev-rus. (date of access: 20.02.2021).

11. B. Mezhuev, In search of 50 honest governors. Retrieved from: https://um.plus/2016/07/29/vpoiskah-50-chestny-h-gubernatorov/ (date of access: 31.01.21).

12. W. Schluchter, The sociology of law as an empirical theory of validity, European sociological review, 5, 537-549 (2003)

13. L.M. Friedman, Coming of Age: Law and Society Enters an Exclusive Club, Annual Review of Law and Society Science, 1, 1-16 (2005) 